UDC 378.147:331.45-051

DOI: $10.31470 / 2415-3729-2019-9-244-258$

\title{
Using of Imitational Teaching Technologies in the Process of Future Labour Specialists Professional Training
}

\section{Yurii Shapran}

Doctor of Pedagogy, Professor, Head of the Department of Theory and Methods of Professional Training

Pereiaslav-Khmelnytskyi Hryhorii Skovoroda State

Pedagogical University,

$\triangle$ 30, Sukhomlynskyi Str., Pereiaslav-Khmelnytskyi, Kyiv

Region, Ukraine, 08401

E-mail: Yrij.shapran@gmail.com

ORCID: 0000-0002-4176-7502

Date of receipt of the article: December 07, 2018

Article accepted for publication: February 21, 2019

\section{Використання імітаційних технологій навчання у процесі професійної підготовки майбутніх фахівців із охорони праці}

\section{Юрій Петрович Шапран}

доктор педагогічних наук, профессор,

завідувач кафедри теорії та методики професійної підготовки

ДВНЗ «Переяслав-Хмельницький державний педагогічний університет імені Григорія Сковороди»,

$\checkmark$ вул. Сухомлинського, 30, м. Переяслав-Хмельницький, Київська обл., Україна, 08401

Дата надходження статті: 07 грудня 2018 р. Стаття прийнята до друку: 21 лютого 2019 р.

\section{Abstract}

The objective of this abstract was to determine the features of the using of the imitational technologies in the educational 
process of labor protection specialists. The theoretical (scientific literature analysis, modeling of specific situations, synthesis and comparison, evaluation and synthesis of collected facts) and empirical (observation, questioning, testing, questioning, conversation, problem solving, game interaction) analyzing methods were used as the main ones. The features of the active teaching methods using were determined. The experience of their implementation in the educational process is discussed. It is proved that the interpersonal interaction of students in the process of vocational training contributes to very many important things. Such things are: the effective formation of skills for emergencies forecasting at military and construction objects, social and educational institutions, industrial enterprises of various forms of ownership; the development of life strategies in order to minimize these destructive influences; the development of adequate measures to prevent possible emergencies etc. The experience of the «Accident at the enterprise» simulation technology using is discussed. An algorithm is proposed which consists of the next stages for the implementation of educational technology: the definition of a goal; the necessary material and equipment selection; the familiarization with the simulation problem content; the normative base of business activity studying; the creation of the investigation expert accident commission; an analysis of the materials received and the investigation of the root causes that led to an accident; the reveal of the officials who committed violations; the development of recommendations for elimination of the revealed violations; summing up and issues discussing. It is important to take into account that the simulation training technologies are the most effective when students acquire future professional activity experience, and analyze the possible variants of activity in the industrial, educational and social spheres. The author notes that the studying of the essential training technologies simulation features provided an opportunity to determine the main advantages of their use in the practice of future labor specialists training.

Key words: educational training technologies; methods of teaching; game interaction; staging of the simulation training technology; active teaching methods; vocational training. 


\section{References}

1. Druz, I. M. (2011). Pedahohichna systema pidhotovky fakhivtsiv v umovakh bolonskoho protsesu [Pedagogical system of training specialists in the conditions of the Bologna process]. Shchokvartalnyi naukovo-praktychnyi zhurnal, 1, 67-72 [in Ukrainian].

2. Ivanenko, L. M. (2007). Imitatsiini ihry - rakursy i perspektyvy [Imitation games - aspects and perspectives]. Visnyk NAN Ukrainy, 5, 58-67 [in Ukrainian].

3. Lozovetska, V. T., Luk'ianova, L. B \& Kozak, L. V. (2010). Formuvannia profesiinoi kompetentnosti fakhivtsia sfery posluh $i$ turyzmu [Formation of the professional competence of a specialist in the field of services and tourism]. Kiev [in Ukrainian].

4. Shapran, Yu. P., Dranytsia, P. Iu. (2017). Vykorystannia ihrovoho imitatsiinoho modeliuvannia pry formuvanni profesiinoi kompetentnosti inzheneriv u haluzi okhorony pratsi [The using of game simulation modeling in the forming of professional competency of engineers in the field of labor protection]. Profesiina osvita: metodolohiia, teoriia ta tekhnolohii, 5/1, 213-227 [in Ukrainian].

\section{Вступ}

Наявні світові інтеграційні процеси, загострення економічної кризи, ймовірні природні катаклізми, виробничі техногенні аварії, необхідність реформування господарської діяльності спонукають до проведення якісних змін у системі професійної підготовки фахівців із охорони праці. Постає проблема щодо необхідності досягнення соціально затребуваного результату освітнього процесу у формі конкурентоспроможного на сучасному ринку праці випускника закладу вищої освіти - компетентного, креативного, ініціативного, мобільного, відповідального, принципового, критичного, стійкого до соціальних упливів, спроможного адаптупатися до постійно плинних умов професійної діяльності, здатного вибудовувати ефективні стратегії досягнення прогнозованого результату, 
самостійного в прийнятті виважених рішень у стандартних і не стандартних ситуаціях тощо.

Компетентність сучасного фахівця визначається у його готовності до реалізації особистісного потенціалу при розв'язанні наявних, переважно важко прогнозованих, виробничих проблем. Ця інтегрована якість високо мотивованої особистості набувається у процесі професійної діяльності. 3 цією метою під час навчання студентів у закладі вищої освіти передбачено проведення різноманітних практик (навчальні, виробничі, педагогічні). Проведений аналіз навчальних планів підготовки фахівців означеного профілю засвідчує не достатню тривалість практичної підготовки, що не сприяє розв'язанню наявної проблеми. Варто зазначити, що виробничі практики, зазвичай, організовуються на останніх курсах професійної підготовки, що перешкоджає ранній професіоналізації студентів. Вище наведене спонукає до висновку щодо необхідності пошуку й апробації нових варіантів викладання матеріалу й використання активних методів навчання. Упровадження в освітній процес закладів вищої освіти інтерактивних технологій навчання $\epsilon$ надзвичайно актуальним, бо це сприяє зануренню студента в професійне середовище його майбутньої діяльності. Використання в освітньому процесі означених технологій $\epsilon$ доцільним за умови проведення моделювання імовірних потенційних виробничих небезпек i ризиків унаслідок ігнорування правилами експлуатації виробничих засобів, порушення виробничих циклів, не дотримання правил техніки безпеки тощо.

Проблема професійних якостей сучасного фахівця розглядається зарубіжними ученими - R. Boyatzis, M. Dalziel, D. Fitt, E. Fleischam, R. Mansfield, J. Marshall-Miles, A. Mitrani, J. Raven, L. Spenser, S. Spenser, C. Uhlman, D. Ulrich, L. Wetrogan та ін. Дослідження різних аспектів підготовки фахівців із цивільного захисту й охорони праці в освітній сфері здійснювали Ю. Буц, П. Волянський, В. Вонсович, В. Губенко, О. Дьоміна, О. Свсюков, Н. Заверуха, В. Зацарний, Д. Зеркалов, О. Запорожець, С. Ільїн, О. Кобилянський, Б. Коржик, О. Крайнюк, В. Лапін, 
А. Матвєєв, В. Матейчик, О. Попова, О. Русак, О. Степанова, А. Терент'єва, А. Ткачук, А. Тушин, Ю. Холмовий, В. Ягупов та ін.

Проблему методики навчання із охорони праці досліджували О. Кобилянський, О. Смірнов, Я. Томашевська, Н. Фадеєва, 3. Яремко та ін., формування готовності до реалізації професійних компетенцій - П. Омельченко, Л. Сорокіна, Л. Сурова, В. Ткаченко, М. Шайденко, В. Щербакова та ін., технологічного забезпечення та удосконалення професійної підготовки - I. Друзь, Д. Зеркалов, О. Запорожець, В. Зацарний, В. Матейчук, I. Самойленко, Я. Сєріков, І. Смоліна, Д. Ступак та ін.

Імітаційні технології навчання висвітлюються у працях О. Вишенської, В. Сфімова, Л. Заїки, Т. Калашнікової, П. Підкасистого, Т. Рижкової, А. Смолкіна, В. Стрельникова, В. Трайнєва та ін. Сучасні наукові дослідження спрямовані на вивчення методології і практики використання імітаційних технологій із метою активізації навчально-пізнавальної діяльності здобувачів вищої освіти й удосконалення процесу професійної підготовки конкурентно спроможних фахівців в умовах сучасного ринку праці.

Аналіз літературних джерел призводить до думки, що наявні дослідження щодо процесу професійної підготовки інспекторів із охорони праці охоплюють лише окремі аспекти вказаної проблеми. На жаль, на сучасному етапі розвитку професійної освіти їх теоретичне обгрунтування виявляє ознаки фрагментарності й не сприяє становленню цілісної системи підготовки кадрів означеного профілю. Зважаючи на проведений аналіз наукової літератури можна стверджувати, що на сьогодні відсутні системні наукові дослідження проблеми професійної підготовки майбутніх фахівців із охорони праці з використанням сучасних освітніх технологій навчання, зокрема імітаційних.

Метою статті є визначення особливостей використання імітаційних технологій навчання у закладах вищої освіти в процесі професійної підготовки фахівців із охорони праці.

\section{Матеріал і методи дослідження}

Дослідження проводилося на базі ДВНЗ «ПереяславХмельницький державний педагогічний університет імені 
Григорія Сковороди» зі студентами, які здобували освітній рівень бакалавр за напрямом підготовки 6.01.01.01 Професійна освіта (Охорона праці). Всього в експерименті брали участь 98 студентів природничо-технологічного факультету. Емпіричний матеріал дослідження накопичувався й узагальнювався упродовж 2016-2018 років. Серед використаних методів досліження визначальними були теоретичні (аналіз наукової літератури з досліджуваної проблематики; моделювання конкретних ситуацій, синтез і порівняння, оцінка й узагальнення зібраних фактів) й емпіричні (спостереження, опитування, тестування, анкетування, бесіди, розв'язування проблемних завдань, ігрова взаємодія). Використані методи дослідження дозволяють стверджувати про ефективність використання в освітньому процесі імітаційних технологій навчання у процесі підготовки фахівців із охорони праці за умови дотримання вимог їх конструювання і проведення.

\section{Результати та їх обговорення}

Положення, що нормують сферу діяльності фахівців із охорони праці наведені в Конституції України, Кодексі цивільного захисту України (2013 р., із змінами), Законах України «Про охорону праці» (1992 р., із змінами), «Основи законодавства України про охорону здоров'я» (1992 р., iз змінами), «Про охорону навколишнього природного середовища» (1991р., із змінами), «Про забезпечення санітарного та епідеміологічного благополуччя населення» (2011 р.), «Про вищу освіту» (2014 р.), Кодексі Законів про працю (2016 р, із змінами), наказі Міністерства освіти та науки України «Про затвердження Положення про організацію роботи 3 охорони праці та безпеки життєдіяльності учасників освітнього процесу в установах $\mathrm{i}$ закладах освіти» (№1669 від 26.12.17 р.) та ін.

Проблема професійної підготовки майбутніх фахівців iз охорони праці в умовах сьогодення $\epsilon$ соціально затребуваною і потребує нагального розв'язання. Вона організовується у відповідності до галузевого стандарту вищої освіти й визначається сучасними соціальноекономічними, освітніми й професійними потребами, що продиктовані ринком праці. 
Професійна компетентність фахівця характеризується такими елементами діяльності: аналіз результатів праці і технологічних процесів; аналіз професійних ситуацій i проблем; аналіз технічної документації завдань діяльності; організація праці; дотримання технічних та технологічних вимог виробництва; координація видів професійної діяльності; створення професійно-значущої інформації щодо об'єкта діяльності; прогнозування типових і нетипових виробничих ситуацій; забезпечення безпечних умов праці; оволодіння додатковими кваліфікаціями і професіями; забезпечення високого рівня культури праці; дотримання правил експлуатації галузевого устаткування; відсутність браку продукції; своєчасне усунення технічних i технологічних порушень; дотримання рекомендацій, норм i вимог щодо фізіологічних, економічних, екологічних i ергономічних чинників (Лозовецька, Лук'янова, Козак, 2010: 11). Визначальне значення у процесі професійної підготовки майбутніх фахівців із охорони праці відведене сучасним освітнім технологіям. Їх, зазвичай, трактують як систему психологічних, загально-педагогічних, дидактичних, методичних процедур взаємодії педагогів і студентів із урахуванням їх здібностей, спрямованих на проектування i реалізацію змісту, методів, форм, засобів навчання, що відповідають меті освіти, змісту майбутньої діяльності й вимогам до професійно важливих якостей фахівців (Друзь, 2011: 70). Серед освітніх технологій особливе місце посідають імітаційні технології навчання, які ще називають технологіями «активного навчання».

Навчання із використанням імітаційних технологій набуває особливого поширення в економіці, освіті, політиці, соціології, екології, адмініструванні тощо. Його використовують у процесі професійної підготовки фахівців, а також із метою прогнозування, апробування пропонованих інновацій. Специфікою імітаційних технологій навчання $є$ моделювання (створення штучної системи) різноманітних взаємозалежностей в умовах реального життя. Їх сутністю $є$ побудова освітнього процесу, що зорієнтований на формування і розвиток у здобувачів вищої освіти ціннісних 
орієнтацій, толерантних взаємин, комунікативної культури, раціональних методів виробничої діяльності (прогнозування, планування, проведення грунтовних аналізів першопричин досліджуваних явищ, рефлексії тощо).

Імітаційні технології навчання сприяють набуттю учасниками освітнього процесу досвіду майбутньої професійної діяльності й забезпечують перенесення отриманих в аудиторії знань і практичних навичок у реальну професійну дійсність. Варто зазначити, що імітаційне навчання розвиває такі особистісні навички як умотивованість, ініціативність, комунікативність, емпатійність, толерантність, автономність, співробітництво, відповідальність тощо.

Імітаційні технології навчання використовують ігрові (ділові й рольові ігри, ігрове проектування) й неігрові (аналіз й обговорення змодельованих ситуацій, розв'язання виробничих проблем, робота із документами) методи.

У процесі гри засвоюються норми професійних i соціальних дій, а також принципи безконфліктного спілкування. Л. Іваненко стверджує, що імітаційна модель, що покладена в основу гри, може бути інформаційною, тобто вона передбачає отримання на вході певних сигналів щодо дій (рішень) гравця - послідовності символів, цифр і реакції на них. Тому ще вживають вислів «модель відгуку». Вона може реалізуватися також у формі макету, тоді сигнали передаються за допомогою ручок, важелів, тумблерів тощо. (Іваненко, 2007: 58). Серед ділових ігор особливе місце відведене ігровому проектуванню (розробка інженерних, технологічних, здоров'язбережувальних й охоронних проектів) й імітаційним тренінгам (напрацювання спеціалізованих навичок й умінь, що необхідні в майбутній професійній діяльності), серед рольових - розіграванню ролей і стажування із виконанням посадової ролі (в їх основі лежать напрацювання комфортних взаємовідносин у колективі).

Неігрові методи забезпечують занурення здобувачів вищої освіти в їх майбутнє професійне середовище, спонукають до грунтовного аналізу наявної (змодельованої) 
ситуації, віднаходження оптимальних шляхів іiі розв’язання шляхом творчого пошуку в умовах активної командної взаємодії.

Результативність імітаційних технологій навчання проявилася у процесі викладання навчальних дисциплін професійно-практичної підготовки: «Теорія горіння та вибуху», «Експертиза 3 охорони праці», «Розслідування, облік і аналіз нещасних випадків, професійних захворювань та аварій» (1 курс), «Безпека життєдіяльності», «Соціальноекономічні основи охорони праці», «Загальна електротехніка та електробезпека», «Основи інженерно-педагогічної творчості», «Організація наглядової діяльності в галузі охорони праці» (2 курс), «Правові основи працеохоронної політики та охорони праці», «Захист у надзвичайних ситуаціях», «Пожежна безпека виробництв», «Виробнича санітарія», «Правила будови та безпечної експлуатації електроустановок споживачів», «Методи розрахунку захисних засобів» (3 курс), «Профілактика виробничого травматизму та професійних захворювань», «Метрологія, стандартизація та сертифікація», «Потенційно небезпечні виробничі технології та їх ідентифікація», «Безпека експлуатації будівель та споруд», «Безпечна експлуатація інженерних систем i споруд», «Безпека експлуатації виробничого устаткування, приладів і пристроїв» (4 курс).

Використання імітаційних технологій навчання призводило до збільшення обсягів здобутих знань і практичних навичок майбутніми фахівцями з охорони праці за певну одиницю часу. Варто зазначити, що шляхом використання комп'ютерних засобів навчання довготривалі виробничі процеси моделювалися із значним прискоренням (допускається деяке спрощення виробничих циклів), що забезпечувало суттєву економію навчального часу й не потребувало безпосередньої присутності здобувачів вищої освіти на підприємстві, не спричиняло їм ніяких загроз (моделювання умов шкідливого й небезпечного виробництв, типових аварійних ситуацій, імовірних техногенних катастроф, порушення експлуатації промислових установок, технологічного циклу, правил техніки безпеки тощо). 
Зазвичай, ситуації, що моделювалися, були дотичними до типових проблем із виробничої, техногенної, побутової i рекреаційної безпек. Отже, використання імітаційних технологій навчання інтенсифікувало освітній процес, активізувало приховані можливості студентів, сприяло набуттю досвіду майбутньої професійної діяльності.

При розробці імітаційних технологій навчання важливим є конструювання і прогнозування різноманітних форм діяльності майбутнього фахівця із охорони праці 3 метою з'ясування сучасних підходів до організації охорони праці на виробництві, потенційних i реальних загроз експлуатації будівель, інженерних систем, споруд, сучасних промислових підприємств тощо. Взаємодія учасників освітнього процесу потребує від них умінь прогнозування виникнення можливих аварійних ситуацій i ризиків, вибудовування адекватних стратегій діяльності, нормування виробничих умов, їх контроль, усунення виявлених недоліків i порушення нормативних законодавчих актів, розв'язання загальних організаційних завдань тощо.

При використанні технологій імітаційного навчання доцільно враховувати етапність їх проведення (Шапран, Драниця, 2017). На першому етапі (підготовчому): визначають мету, завдання, місце й час проведення; 3'ясовують відповідність освітньої технології етапу професійної підготовки; формують (моделюють) проблемну ситуацію, що пов'язана з тематикою заняття, розробляють відповідний сценарій і визначають імовірні етапи взаємодії учасників освітнього процесу (аксіологічно-мотиваційний, когнітивно-операційний, контрольно-оцінювальний, рефлексивний); готують відповідний інформаційний i методичний супровід.

Другий етап (ігрова складова, міжособистісна взаємодія) забезпечує когнітивно-операційну сферу освітньої технології, яка характеризується прогнозуванням студентами кінцевого результату, вибором й обгрунтуванням оптимальних шляхів його досягнення, здатністю ефективно працювати в команді, спільним прийняттям рішень, спроможністю до раціональних способів міжособистісної 
взаємодії, умінням вибору ефективних шляхів розв'язання наявної проблеми, творчим професійним мисленням тощо. Діяльність студентів на вказаному етапі технології визначається суперництвом, емоційністю, комунікативністю, креативністю i нормується відповідними правилами й інструкціями.

Третій етап (аналітично-оцінювальний) передбачає узагальнення отриманих студентами результатів, обговорення варіантів і вибір раціональних шляхів розв'язання змодельованої проблеми, підведення підсумків, оцінювання й аналіз кожного учасника власної діяльності 3 метою подальшого особистісного професійного зростання і рефлексії, установлення викладачами виявлених помилок $\mathrm{i}$ з'ясування шляхів удосконалення комунікативної взаємодії студентів із метою подальшого використання апробованої технології.

Наведемо приклад використання освітньої технології імітаційного навчання «Нещзасний випадок на виробництвві» при вивченні навчального предмета «Розслідування, облік і аналіз нещасних випадків, професійних захворювань та аварій» (1 курс).

Метою технологї є формування відповідального ставлення у здобувачів вищої освіти до проблеми безпеки експлуатації виробничих засобів, уміння фахово реагувати на різноманітні нестандартні виробничі ситуації, формування ціннісного ставлення до здоров'я людини.

Матеріали й обладнання: комп'ютерна техніка, інтерактивна дошка, опис виробничих засобів підприємства (будівлі, споруди, передавальні пристрої, машини й устаткування, транспортні засоби, виробничий i господарський інвентар тощо), відеофрагмент виробничого циклу (підготовлений старшокурсниками під час проходження ними виробничої практики), внутрішні приписи й інструкції щодо правил експлуатації ємностей із вибухонебезпечними речовинами, копії посадових обов'язків інженера 3 охорони праці, відеоролики «Аварія на Васильківському складі горючо-мастильних матеріалів», «Надання первинної медичної допомоги при глибинних 
опіках шкіри». У процесі реалізації імітаційної технології навчання передбачалося створення експертної комісії із метою розслідування причин і наслідків нещасного випадку, що був пов'язаний із отриманням численних опіків тіла робітником унаслідок проведення ремонтних робіт у небезпечній зоні зберігання вибухонебезпечних речовин.

Завданням експертної комісії було з'ясування причин травмування працівника, визначення провини посадових осіб, які причетні до цього випадку.

Реалізація освітньої технології здійснювалася почергово:

1) ознайомлення студентів із виробничим циклом підприємства;

2) вивчення нормативної бази ведення господарської діяльності, ознайомлення із правилами експлуатації ємностей для зберігання вибухонебезпечних речовин, імовірними ризикованими наслідками їх експлуатації;

3) створення експертної комісії із метою розслідування нещасного випадку (огляд місця пригоди; бесіда iз потерпілим, опитування очевидців, посадових осіб, які були відповідальні за безпечну експлуатацію виробничого обладнання; вивчення нормативної, виробничої і первинної документації; перевірка технічного стану обладнання);

4) аналіз отриманих матеріалів розслідування і з'ясування першопричин, що призвели до нещасного випадку;

5) визначення посадових осіб, які допустили порушення інструктивних (нормативних) вимог й умов експлуатації засобів виробництва, не дотримання правил техніки безпеки праці;

6) розробка рекомендацій щодо ліквідації виявлених порушень й уникнення аналогічних нещасних випадків у майбутньому;

7) підведення підсумків, обговорення виниклих проблем, оцінювання й самоаналіз діяльності здобувачів вищої освіти, встановлення виявлених порушень експлуатації й обслуговування ємностей для зберігання вибухонебезпечних речовин і шляхів їх подолання. 


\section{Висновки}

Отже, проведений аналіз сутнісних ознак імітаційних технологій навчання надає змогу визначити основні переваги їх використання у практиці професійної підготовки майбутніх фахівців із охорони праці. Вони є ефективними при набутті здобувачами вищої освіти досвіду майбутньої професійної діяльності, адаптації, проведенні аналізу типових моделей реальності (на зразках професійних дій представниками різних рольових й особистісних позицій). При розробці імітаційних технологій навчання важливо дотримуватися їх етапності, при конструюванні ураховувати різноманітні форми діяльності майбутнього фахівця із охорони праці в умовах реального виробництва 3 метою прогнозування виникнення можливих аварійних ситуацій і ризиків, вибудовування адекватних стратегій діяльності, нормування виробничих умов, їх контроль, усунення виявлених недоліків і порушення нормативних законодавчих актів, розв'язання загальних організаційних завдань тощо.

Перспективи подальших розвідок убачаємо в напрямку подальшої розробки інтерактивних освітніх технологій і впровадження їх у практику професійної підготовки майбутніх інженерів із охорони праці.

\section{Література}

1. Друзь I. М. Педагогічна система підготовки фахівців в умовах болонського процесу. Щоквартальний науковопрактичний журнал. 2011. № 1. С. 67-72.

2. Іваненко Л. М. Імітаційні ігри - ракурси й перспективи. Вісник НАН України. 2007. № 5. С. 58-67.

3. Лозовецька В. Т., Лук'янова Л. Б., Козак Л. В., Формування професійної компетентності фахівця сфери послуг і туризму : навч.-метод. посіб. за заг. ред. Лозовецької В. Т. Київ. 2010. 382 с.

4. Шапран Ю.П., Драниця П.Ю., Використання ігрового імітаційного моделювання при формуванні професійної компетентності інженерів у галузі охорони праці. Професійна освіта: методологія, теорія та технологіï. 2017. Вип. 5/1. С.213-227. 


\section{Шапран Ю.П.}

Використання імітаційних технологій навчання $\mathbf{y}$ процесі професійної підготовки майбутніх фахівців із охорони праці

\section{Анотація}

Обговорюються можливості використання технологій імітаційного моделювання у процесі професійної підготовки фахівців із охорони праці. Визначено особливості використання активних методів навчання, обговорюється досвід їх упровадження в освітній процес. Доведено, що міжособистісна взаємодія студентів у процесі фахової підготовки сприяє ефективному формуванню професійних умінь, що дозволяє вибудовувати обгрунтовані стратегії мінімізації деструктивних упливів, розробляти адекватні заходи з метою уникнення імовірних аварійних ситуацій. У процесі використання імітаційних технологій навчання важливе місце відведене процесу їх конструювання. При їх розробці важливо дотримуватися етапності (підготовчий, міжособистісної взаємодії, аналітично-оцінювальний), при конструюванні - ураховувати різноманітні форми діяльності майбутнього фахівця із охорони праці в умовах реального виробництва. Обговорюється досвід використання імітаційної технології «Нещасний випадок на підприємстві». Запропоновано алгоритм іï реалізації. Зазначено, що технології імітаційного навчання є ефективними при набутті студентами досвіду майбутньої професійної діяльності, здійсненні аналізу можливих варіантів професійних дій у не стандартних ситуаціях.

Ключові слова: освітні технології; методи навчання; ігрова взаємодія; активні методи навчання; фахова підготовка.

\section{Шапран Ю. П.}

Использование

имитационных

технологий

обучения в процессе профессинальной подготовки будущих специалистов по охране труда 


\section{Аннотация}

Обсуждаются возможности использования технологий имитационного обучения в процессе профессиональной подготовки специалистов по охране труда. Определены особенности использования активных методов обучения, обсуждается опыт их внедрения в образовательный процесс. Доказано, что межличностное взаимодействие студентов в процессе профессиональной подготовки способствует эффективному формированию профессиональных умений, позволяет выстраивать обоснованные стратегии минимизации деструктивных влияний, разрабатывать адекватные меры во избежание возможных аварийных ситуаций. В процессе использования имитационных технологий обучения важное место отведено процессу их конструирования. При их разработке важно придерживаться этапности (подготовительный, межличностного взаимодействия, аналитически-оценочный), при конструировании - учитывать различные формы деятельности будущего специалиста по охране труда в условиях реального производства. Обсуждается опыт использования имитационной технологии «Несчастный случай на предприятии». Предложен алгоритм ее реализации. Отмечено, что технологии имитационного обучения эффективны при приобретении студентами опыта будущей профессиональной деятельности, осуществлении анализа возможных вариантов профессиональных действий в нестандартных ситуациях.

Ключевые слова: образовательные технологии; методы обучения; игровое взаимодействие; активные методы обучения; профессиональная подготовка. 